\title{
PIIISGUC.ORG
}

"iş, GÜÇ" ENDÜSTRI iLişKILERI VE INSAN KAYNAKLARI DERGISi

"IS, GUC" INDUSTRIAL RELATIONS AND HUMAN RESOURCES JOURNAL

\section{Siyaset Ahlakı İle İş Ahlakına Teorik Bir Bakış}

\author{
Öğr.Gör.Dr. Abdulvahap AKINCI
}

Kocaeli Üniversitesi, Gazanfer Bilge MYO

Nisan/April 2013, Cilt/Vol: 15, Say1/Num: 2, Page: $82-96$

ISSN: 1303-2860, DOI: 10.4026/1303-2860.2013.0227.x

Makalenin on-line kopyasına erişmek için / To reach the on-line copy of article: http://www.isguc.org/index.php?p=article\&id=512\&cilt=15\&sayi=2\&yil=2013

Makale İçin İletişim/Correspondence to:

Dr.Abdulvahap Akınc1/ email: akakinci1@yahoo.com.tr 


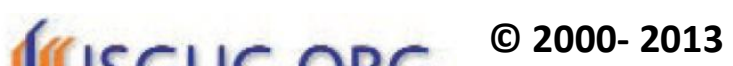 \\ "İş,Güç" Endüstri ilişkileri ve İnsan Kaynakları Dergisi "Işs,Güç" Industrial Relations and Human Resources Journal
}

\author{
Nisan/April 2013, Cilt/Vol: 15, Say1/Num: 2, \\ Sayfa/Page: 82-96, DOI: 10.4026/1303-2860.2013.0227.x
}

"Işs,Güç" Endüstri İlişkileri ve İnsan Kaynaklarn Dergisi, yılda dört kez yayınlanan hakemli, bilimsel elektronik dergidir. Çalışma hayatına ilişkin makalelere yer verilen derginin temel amacl; belirlenen alanda akademik gelişime ve paylaşıma katkıda bulunmaktır.

"İ̧s,Güç" Endüstri İlişkileri ve İnsan Kaynakları Dergisi'nde, 'Türkçe' ve 'İngilizce' olarak iki dilde makale yayınlanmaktadır. "İş,Güç" Endüstri İlişkileri ve İnsan Kaynakları Dergisi, ulusal ve uluslararası birçok indekste taranmaktadır. (Cabell's Directories, Ebsco Socindex, Index Islamicus, Index Copernicus International, Worldwide Political Science Abstracts, Sociological Abstract, Ulakbim Sosyal Bilimler Veritaban,, ASOS Index)

Editör / Editor in Chief

Aşkın Keser (Uludağ University)

\section{Editör Yardımcıları / Co-Editors}

Şenol Baştürk (Uludă̆ University)

K.Ahmet Sevimli (Uludağ University)

Gözde Yllmaz (Marmara University)

\section{Uygulama / Design}

Yusuf Budak (Kocaeli University)

Tarandı̆̆ı Indeksler / Indexes ASOS INDEX

CABELL'S DIRECTORIES

EBSCO SOCINDEX

Index ISLAMICUS

Index COPERNICUS Int.

Sociological Abstract

ULAKBİM Sosyal Bilimler

Veritanı

Worldwide Political Science

Abstracts

\author{
Yayın Kurulu / Editorial Board \\ Dr.Şenol Baştürk (Uludă̆ University) \\ Yrd.Doç.Dr.Zerrin Fırat (Uludă̆ University) \\ Doç.Dr.Aşkın Keser (Uludă̆ University) \\ Prof.Dr.Ahmet Selamoğlu (Kocaeli University) \\ Yrd.Doç.Dr.Ahmet Sevimli (Uludağ University) \\ Doç.Dr.Abdulkadir Şenkal (Kocaeli University) \\ Doç.Dr.Gözde Yılmaz (Marmara University) \\ Yrd.Doç.Dr.Memet Zencirkıran (Uludağ University)
}

Uluslararası Danışma Kurulu / International Advisory Board

Prof.Dr.Ronald Burke (York University - Kanada)

Assoc.Prof.Dr.Glenn Dawes (James Cook University - Avustralya)

Prof.Dr.Jan Dul (Erasmus University - Hollanda)

Prof.Dr.Alev Efendioğlu (University of San Francisco - ABD)

Prof.Dr.Adrian Furnham (University College London - Ingiltere)

Prof.Dr.Alan Geare (University of Otago - Yeni Zellanda)

Assoc. Prof. Dr. Diana Lipinskiene (Kaunos University - Litvanya)

Prof.Dr.George Manning (Northern Kentucky University - ABD)

Prof.Dr.Mustafa Özbilgin (Brunel University - UK)

Assoc. Prof. Owen Stanley (James Cook University - Avustralya)

Prof.Dr.Işık Urla Zeytinoğlu (McMaster University - Kanada)

Ulusal Danışma Kurulu / National Advisory Board

Prof.Dr.Yusuf Alper (Uludağ University)

Prof.Dr.Veysel Bozkurt (İstanbul University)

Prof.Dr.Toker Dereli (Işık University)

Prof.Dr.Nihat Erdoğmuş (İstanbul Şehir University)

Prof.Dr.Ahmet Makal (Ankara University)

Prof.Dr.Süleyman Özdemir (İstanbul University)

Prof.Dr.Ahmet Selamoğlu (Kocaeli University)

Prof.Dr.Nadir Suğur (Anadolu University)

Prof.Dr.Nursel Telman (Maltepe University)

Prof.Dr.Cavide Uyargil (İstanbul University)

Prof.Dr.Engin Yıldırım (Anayasa Mahkemesi)

Doç.Dr.Arzu Wasti (Sabancı University)

Dergide yayınlanan yazılardaki görüşler ve bu konudaki sorumluluk yazarlarına aittir.

Yayınlanan eserlerde yer alan tüm içerik kaynak gösterilmeden kullanılamaz.

All the opinions written in articles are under responsibilities of the authors.

The published contents in the articles cannot be used without being cited. 


\title{
Siyaset Ahlakı İle İş Ahlakına Teorik Bir Bakış
}

\author{
Öğr.Gör.Dr. Abdulvahap AKINCI \\ Kocaeli Üniversitesi, Gazanfer Bilge MYO
}

\section{A Theoretical Eye On The Ethics Of Business And Policy}

\section{Abstract}

The non-ethical behaviours in political and business life have been attracting much more attention of the individuals with the rapid advance of communication opportunities. By virtue of the fact that the individuals are more organised and conscious, both politicians and businessmen have felt that they have to behave more cautious. The politicians and companies who want to build good relationships with the society realised that they should establish trust among people in order to sell their products or be elected again. In this context, the term ethic became the main topic of the conversation. Many scholars have stated that the poltical and general ethic may not be the same since Machiavelli. On the contrary, there are also some others argue that the ethics have general principles in all fields.

In this study we have examined and put forward the difference between the political ethic and business, dealing with the labour and work ethics. The relation between political and business ethics have been studied in a theoretical way.

Keywords: Political Ethics, Work Ethics, Labour Ethics, Business Ethics, Ethics

Özet:

Siyasette ve iş hayatında yapılan ahlaki olmayan tavırlar, iletişim imkanlarının hızla gelişmesiyle birlikte bireylerin çok daha fazla dikkatini çekmeye başladi. Bireylerin daha organize ve bilinçli olmaları dolayısıla gerek siyasiler, gerekse iş dünyası kendini daha dikkatli davranmak zorunda hissetti. Toplumla iyi bağlar kurmak isteyen siyasiler ve şirketler, tekrar seçilebilmek /mal ve hizmetlerini daha iyi satabilmek için topluma güven vermek zorunda olduklarının farkına vardılar. Bu bă̆lamda etik kavramı daha fazla gündeme geldi. Machiavelli'den bu yana bir çok düşünür, siyaset ahlakı ile genel ahlakın aynı olamayacağı üzerinde durdular. Bu yaklaşımın tam tersine ahlakın her alanda genel ilkeleri olduğunu savunanlar da mevcuttur.

Bu çalışmada siyaset ahlakı ile iş, çalışma ve meslek ahlakı ele alınarak aralarındaki ilişki ortaya konmaya çalışılmıştır. Siyaset ahlakı ile iş ahlakı arasındaki ilişki teorik bir çerçevede irdelenmiştir

Anahtar Kelimeler: Siyaset Ahlakı, İş Ahlakı, Çalışma Ahlakı, Meslek Ahlakı, Etik 
"iş, GÜç" Endüstri İlişkileri ve İnsan Kaynakları Dergisi

"IS, GUC" Industrial Relations and Human Resources Journal
Nisan/April 2013 - Cilt/Vol: 15 - Sayı/Num: 02

Sayfa/Page: 01-13, DOI: 10.4026/1303-2860.2013.0227.x

\section{GİRIŞ}

Hızla gelişen teknolojinin bir sonucu olarak şirketler, dünya geneline dönük üretim yapma imkanını elde etmeye başladılar. Bu süreçte, üretim ilişkilerinde de önemli değişiklikler oldu; fordist üretimden postfordist üretime geçildi. Fordist üretimde herhangi bir ürün üretilmeye başlandığında uzun zaman diliminde ve aynı şekilde üretilirdi. 70'lerden başlayarak insanların tüketim alışkanlıkları hızla değişmeye başladı. Artık farklı ürünler talep edilmeye başlandı. İşletmeler seri üretim yerine küçük partiler halinde üretim yapma yoluna gitmeye başladılar. Rekabetin olanca hızıyla artması, beraberinde şirketlerin aç gözlü tavır takınmalarına ve maliyetleri olabildiğince düşürme çalışmalarına neden oldu. Şirketlerin, maliyetleri düşürmek için başvurdukları yöntemlerin önemli bir bölümü ahlaki değildi. Gelişen iletişim teknikleri sayesinde dünyanın her yeriyle ilgili haberlere anında ulaşılabilir oldu. Bu iletişim kolaylığı, şirketlerin etik olmayan uygulamalarının tüm toplum kesimleri tarafından öğrenilmesine neden oldu. Şirketler, bu şartlar altında tüketicilerin güvenini kazanmak ve ticaret alanında daha kalıcı olmak için etik değerleri dikkate alan çalışmalar yapmaya başladılar.

İnsanlar tarihin her döneminde kimler tarafından yönetildiğini, bu kişi veya kişilerin hangi özelliklere haiz olduklarını düşünegelmişlerdir. $\mathrm{Bu}$ açıdan, yönetenlerin eleştirel bir yaklaşıma tabi tutulması doğaldır. Siyasetin toplumsal talep ve beklentilerden bağımsız hareket etmesi düşünülemez. Bir taraftan siyaset topluma yön vermeye çalışırken, diğer taraftan da siyaset talep ve beklentiler tarafından şekillendirilir. Siyasilerin toplumsal talep ve beklentilere dönük olarak ortaya koydukları bazı faaliyetler ile vatandaşların bazı talep ve beklentileri ahlaki tartışmalara neden olmaktadır. Özellikle rüşvet, adam kayırma gibi ahlak dışı uygulamalar siyasetin kirlenmesine ve halkın siyaset kurumuna olan güveninin zedelenmesine neden olur. Günümüz demokrasinin kurumsallaştığı ülkelerde, yönetimlerin şeffaf olması ve toplumsal kontrolün daha fazla ön plana çıkması sağlanmaya çalışılmaları esastır.

Makalemizde literatür taraması sonucu elde edilen veriler işlendikten, siyaset, iş ve meslek ahlakı irdelendikten sonra aralarındaki benzerlik ve farklılıklar tartışılacaktır.

\section{Kavramsal Çerçeve: Siyaset, İş, Çalışma ve Ahlak Kavramları}

Siyaset ve politika kelimeleri her ne kadar günümüzde aynı anlamda kullanılsalar da, kökenleri ve geldikleri kültürler farklıdır. Politika kelimesi eski Yunanca şehir devleti anlamına gelen "polis" kelimesinden gelmektedir. (Türköne, 2008: 4) Polis, vatandaşlar için üyesi olunduğu gurur duyulan bir yapılanmadir. Ayrica polis devlet anlaminda kullanılırken, politeia ise anayasa veya cumhuriyet, politikos, devlet adamı; politike, devlet yönetme sanat1; politis, vatandaş anlamında kullanılmaktaydı (Akyüz, 2009: 94; Çam, 2000: 21-22).

Politika kavramı ülkeyi yönetme, devlet işlerini yürütme, devletlerarası ilişkileri düzenleme sanatı anlamı yanında, her hangi bir konuda takip edilen yol ve yöntem anlamina da gelmektedir. Siyaset kelimesi ise Arapça'da at eğitimi kelimesinden, seyis kelimesi de aynı kökenden gelmekle birlikte bu kelimeyi bu gün Araplar, siyaset kavramını rezil etmek anlamında kullanmaktadırlar. Türk/Osmanlı geleneğinde ise siyaset bir taraftan yönetim sanatı olarak görülürken diğer taraftan da gerek kamu düzenini bozanlara gerekse devlete karşı işlenen suçlarda verilen cezaları ifade etmektedir (Akyüz, 2009: 94).

Siyasetin ne olduğuna dair çok farklı tanımlamalar yapılmaktadır. Kimisine göre siyaset bir çatışma ve mücadele halidir. Amaç, iktidarın sağladığı imkanları ele geçirmektir. Kimilerine göre ise siyaset bir uzlaşıdır. Ortak çıkarların sağlanması siyaset vasıtasıyla mümkün olabilir (Kapani, 1997: 17-18; Öztekin, 2001: 1-2).

Siyaset, kişileri etkileyerek onların kanaatlerini belli yönlere kanalize etmektir. Yani kullanılan yöntemlerle kişilerin kanaatleri etkilenmeye, kanaati olmayanların ise istenilen şekilde bir 
kanaat sahibi olmaları sağlanmaya çalışılır. $\mathrm{Bu}$ bağlamda bakıldığında siyasetin sorun çözücü yönünden ziyade insanları yönlendirme tarafı ön plana çıkmaktadır (Akyüz, 2009: 94). İnsanların büyük bir bölümünün bir çok konuda herhangi bir fikri yoktur. Siyasetle, kamuoyu istenilen yöne kanalize edilmesi amaçlanır.

Günümüzde bir çok durumda birbiri yerine kullanılmakta olan ahlak ve etik kavramlarının kökenlerine bakmakta fayda vardır. Etik, Grekçe "ethos"tan türetilmiştir; karakter ve alışkanlık anlamına gelir. Bizdeki ahlak kelimesinin batı dillerindeki karşılığı olan moral kelimesi ise Latince "mos"tan (çoğulu mores) türetilmiştir ve yine alışkanlık, adet, karakter anlamına gelmektedir. Her ne kadar aynı anlamda olsalar da zaman içerisinde farklı anlamlarda kullanılmaya başlanmıştır (Poyraz, 16). Normatif ve betimleyici etik anlayışları olarak etik konusundaki yaklaşımları ikiye ayırmak mümkündür. Normatif etik, nasıl davranılması gerektiğinin üzerine yoğunlaşırken, betimleyici etik, realitede insanların nasil davrandiklarının ve bu tutumların nedenlerinin üzerinde durur (TÜSİAD, 2009: 33). Etikle ilgili yapılan farklı tanımlamalara rağmen, temelde vurgulanan kişinin kendisine yapılmasını istemediğini başkalarına yapmamasıdır (Güner, 2002: 20).

Genellikle ahlak ve etik kavramları birbiri yerine kullanılmaktadır. İşletme yönetimi alanında daha ziyade etik kavramı kullanılmaktadır (TÜSİAD, 2009: 31). Bu iki kavram arasında önemli bir fark vardır. Ahlak, toplumsal hayatta bireylerden uymaları talep edilen ve beklenen davranışlardır ki ahlaki davranışlar "iyi" ve "güzel" gibi nitelenirler. En eski felsefi disiplinlerden olan etik ise bireylerin hangi davranışları gerçekleştirmeleri gerektiğini söylemez ve normlar oluşturmaz. Bunun yerine yapilması istenen eylemlere dönük olarak sorular soran, hangi eylemin gerçekleştirilmesinin doğru olduğu, hangi eylemin değerli, hangilerinin değersiz olduğu, adalet ve doğru eylemin ne olduğu vb. sorular sorma faaliyetidir. Etik, bir ahlak felsefesi yapma faaliyeti, ahlak üzerinde düşünme yani ahlaka dönük olarak gelişmiş olan bir felsefe disiplinidir (Dursun, 2005: 17-18). Diğer bir ifadeyle etik düşünülen, ahlak ise yaşanılandır (Poyraz, 16; Sakal ve Kitapçı, 2009: 34). İnsanın evrene karşı duruşunu bilgisi ile beraber etik yargıları belirlemektedir (Bayram, 16).

Arapça olan ahlak kavramı "hulk" kelimesinin çoğuludur ve "huy" anlamına gelmektedir. Ahlak kavramı genel olarak toplumda zaman içerisinde oluşmuş olan, örf ve adetlerin, normların, kurallarının ve değer yargılarının meydana getirmiş olduğu sisteme denmektedir. Ahlak kuralları, gerek bireylerin gerekse toplumun neyi yapip neyi yapmaması gerektiğini yani genel kabul gören doğru ve yanlışları ortaya koymaktadır. Ahlak kuralları her toplum için hatta toplum içindeki her kişi ve grup için doğru olarak kabul edilmek zorunda değildir. Bir toplum için ahlaki olan bir tavır başka bir toplum için ahlak dışı olabilir (Akyüz, 2009: 96). Dursun'a göre belirli toplumsal alanlarda kendilerinden talep edilen ve beklenen tavirlar ahlak çerçevesi içerisinde görülürken, bunun tersi tavırlar ise ahlak dışı olarak görülmektedir. Bu kavramların anlam çerçeveleri farklı olsa da birbirlerini tamamlamaktadırlar (Dursun, 2005: 17).

Smith ve Smith'e göre toplumda refahin sağlanmasında en temel etmenlerin başında din ve ahlak gelmektedir (Smith ve Smith, 2007: 382). Ahlak, bilinçte kurularak hayata geçirildiği durumda, kişiyi bağlayıcı olan bir sürü kuraldan ibaret olmaktan çıkarak bireyi özgürleştirecektir. Bu süreçte ahlak, aynı zamanda insanın insanlaşma süreci konumuna gelmiş olur (Poyraz, 16). Ahlak toplumun bireylere giydirdiği bir elbisedir aynı zamanda. Toplum, arzu ettiği çerçeveyi bireylere sunmakta ve onlardan bu kurallara uymalarını beklemektedir. İçinde doğduğumuz ahlak "dış ahlak" olarak nitelendirilir. "İç ahlak" diye adlandırılan bireyin ahlakı ancak bu diş ahlak sayesinde mümkün olur. Dış ahlak, iç ahlakın oluşmasını sağlayamıyorsa, ortaya içi boşaltılmış bir ahlak çıkar ki bu durum ahlakın ölümü olarak adlandırılır. Dış ahlak iç ahlakın oluşmasını sağladığı müddetçe bir anlam ifade eder ve zorunludur. Ahlak anlayışları kişiyi olgunlaştırarak ideal insan tipinin ortaya çıkmasını sağlamak ister. Bundan dolayı ahlak 
anlayışları bir toplum ve insan tasavvuruna dayanmak zorundadır (Poyraz, 17). Ahlakın zora dayalı bir yaptırımı yoktur, yaptırım vicdani ve manevidir. Ahlaki ilkelerin yerine getirilmesi insan vicdanı tarafından emredilmekte ve ahlaka aykırı bir tavır sergilendiği zaman bunun hesabını önce vicdanına vermek durumundadır. Tabi bu tavırların halk tarafından algılanışı aynı zamanda onların vicdanında mahkum olmayı doğurur. Ahlak insana hak kazandırmaz, vazife yükler (Usta, 2012: 408). İnsanlar ahlak sayesinde daha geniş hareket alanından ziyade, sınırlandırılmış bir alanda hareket etmek zorunda kalırlar. Çünkü bazı şeylerin yapılmaması gerektiğini ahlak anlayışı bireylere vermektedir.

Etik teoriler genellikle sonuçsalcı (teleolojik) ve sonuçsalcı olmayan (deontolojik) olmak üzere ikiye ayrılmaktadır. Sonuçsalcı yaklaşıma göre eylemi iyi veya kötü yapan, sonucudur. Yani bir eylem fayda sağliyorsa (süreç içerisinde bazı kötü şeyler olsa dahi) iyidir. Eylem kendi başına iyi veya kötü olamaz. Sonuçsalcıllğa göre işçilerin motivasyonunu yükseltmek için doğruları tam olarak söylememekte bir sakınca yoktur ve hatta gerekebilir. Sonuçta faydalı olacaksa, bu tür bir davranış iyidir. Immanuel Kant'ın geliştirmiş olduğu deontolojik yaklaşıma göre (sonuçsal olmayan) önemli olan eylemin sonucu değil, kendisidir. Görev ve sorumluluk anlamina gelmekte olan deontolojiye göre ahlaki davranışlar her durumda ve koşulda aynı şekilde ortaya konmalıdırlar. Ahlakın temelini herkes için geçerli doğrular oluşturmaktadır ve sonucunun faydalı olması bir eylemi ahlaki yapmaz. Kantçı yaklaşıma göre bir işletmenin işçilerine sağlayacağı güvenlik ve sağlık imkanları insanlara saygı ilkesinin bir gerekliliğidir (TÜSİAD, 2009: 34-36). Etik kuramı günümüzde teleolojik (sonuçsalcı) kuram olarak ele alınıyor (Usta, 2012: 409).

Etik kavramı, örgüt ve yönetim literatüründe 1980 sonrasında önem kazanmıştır. 1960 ve 1970'li yıllarda etik konusu "işletmelerin sosyal sorumluluğu" başlı̆̆ 1 altında incelenir. 1980'li yıllardan başlayarak başta ABD' de olmak üzere bir çok işletmede "etik ilkeleri", "etik komiteleri" ve "etik programları" oluşturulmuştur. Aynı dönemde yüksek lisans programlarında "etik" bir ders olarak okutulmaya başlanmıştır (Bolat ve Seymen, 2003: 69). Aslında bu durum küreselleşmenin etkisi ile daha ön plana çıkmıştır. Eskiden ağırlıklı olarak üretim iç pazarlara dönük yapılırken, artan küreselleşmeyle birlikte çokuluslu şirketler artmaya başladı ve şirketler dünyanın her yerinde var olma mücadelesi vermeye başladılar. Üretilen ürünlerde bazı asgari standartların olması bir zorunluluk haline geldi. Ayrıca çevreye karşı artan bilinç, şirketlerin bu konuda daha duyarlı olmalarına neden oldu.

Toplumsal düzenin sağlanması için "iyi-kötü" nitelemeleri ile ortaya konan ahlaki kurallar toplumsal alanın her alanına dönüktür. $\mathrm{Bu}$ bağlamda ekonomiden kültüre, iş ahlakından siyasete kadar toplumsal hayatın sürdügü her alana dönük ahlak kuralları kendini gösterir (Bulut, 2007: 2). Etik anlayışı toplumdan topluma ve zaman içerisinde değişebilmektedir (TÜSİAD, 2009: 32). Eski Yunandan beri bir çok düşünür yasalara uygun davranmanın yani iyi bir yurttaş olmanın iyi bir insan olmanın garantisi olmadığının altını çizmiştir. Yani siyasetin ilkeleri ile etik kurallar her zaman örtüşmeyebilir hatta çatışabilir (Bayram, 16-17).

Kullanım değeri olan mal ve hizmet üreten bütün etkinlikler çalışma olarak tanımlanabilir. Çalışma ahlakı ve meslek etiği modern dönemlere ait birer kavramdırlar. Pre-modern insanlar doğal ve sade insanlardı ve premodern dönemde bugünkü anlamda bir çalışma söz konusu değildi. İnsanlar kendi ihtiyaçlarını karşılamaya dönük bir faaliyet içerisindeydiler ve ekonomik hayatta belirleyici olan gelenekler ve atalardan kalan yöntemlerdi. Modern manada çalışma, sanayileşme sürecine paralel olarak toplumsal hayatta merkezi bir yer edindi ve kamusal alanda gerçekleştirilen bir faaliyet haline geldi. Kamunun ve özel sektörün iş gücüne olan yoğun talebi dolayısıyla "çalışma disiplini" bir zorunluluk haline geldi. Bu dönemde aile ve iş birbirinden ayrıldı ve toplumsal ilişkiler özellikle çalışma yaşamında biçimselleşmiş, akılcı ilkeler çerçevesinde oluşturulan bürokratik yöntem ve 
ilkeler belirleyici olmuştur. İnsani duygular geri plana itilerek mekanik bir çerçevede insani ilişkiler düzenlenmeye çalışıldı (Usta, 2012: 410412). Dolayısıyla geleneksel değerler değil modern devletin ortaya koyduğu normatif kurallar çerçevesinde iş ilişkileri düzenlenmeye başland1.

\section{Siyaset Ahlakı}

Siyaset yoluyla toplumun bütün bireylerinin hayatını doğrudan ilgilendiren kararlar alınmaktadır. Dünyada üzerinde en çok tartışmanın yaşandığı konulardan biri de siyaset kurumu ve onun toplumla olan ilişkileri ve bu ilişkinin ahlaki çerçevesidir.

Siyasetin en tartışmalı noktalarından birisini paylaşım sorunu oluşturmaktadır. Aristo'ya göre toplumu bir arada tutan şey karşılıklılık prensibidir. Diğer işlerde olduğu gibi devlet yönetiminde de aynı insanlar ne kadar uzun zaman bulunurlarsa o kadar iyi olur. Fakat bu yaklaşımın çok adil olduğu söylenemez. Çünkü eşit yurttaşların yönetime eşit bir şekilde katılmaları daha hakça olacaktır.

Peki siyasal ahlak dendiği zaman ne anlaşılması gerekir? Farklı tanımlamalar bulunmaktadır bu konuda. Siyasal ahlak, kurumların, siyasal yapıların, rollerin, eylem ve düşüncelerin, toplumsal hayatın uyumlu, olanakl, verimli ve olumlu sürmesini sağlayacağı düşünülen normlardır. Siyasal ahlak, devlet yönetiminde yöneten ve yönetilenlerin uymaları gereken ilkeler, kurallar ve yöntemlerin tümü olarak da tanımlanabilir (Akyüz, 2009: 98).

Siyasilerin seçilebilmek için seçmenlere verdikleri sözleri seçildikten sonra unutmaları, kendi çıkarlarını kamusal çıkarın önünde tutmaları ve hatta bazen yasadışı yapılanmalar ile işbirliği yapmaları siyasette ahlak ve etik tartışmalarına neden olmaktadır (Dursun, 2005: 17). Siyasetin bir araç olmaktan çıkarılıp amaç haline dönüştürüldüğü durumda ortaya siyasi yozlaşma çıkmaktadır (Sakal ve Kitapçı, 2009: 33).

Siyasetin daha ziyade bir mücadele ve iktidarı elde etme, güçten pay alma mücadelesi olarak görüldüğü, iktidarın yozlaştırıcı etkisinden bahsedildiği bir yapıda siyasetçiler hakkında olumsuz bir yargının oluşması kaçınılmazdır. Böyle bir yapıda iktidar sahiplerinde ahlaki özelliklerin olması da pek beklenemez. Siyaset hakkındaki bu olumsuz alg1 değișmelidir (Aktay; 2008: 8). Bir taraftan siyaseti kötü özelliklerle dolu bir şekilde kabul edip, diğer taraftan da ondan erdemli olmasını beklemek doğru olmaz. Siyasette etik dışı tavırların sergilenebilmesi mümkün olmakla beraber, etik çerçeve içerisinde yürütülmesi de mümkündür. Siyasetin etik çerçevede yapılması siyasetçilerin inisiyatifine bırakılmamalı, gerekli önlemler alınmalıdır.

Bayram'a göre siyasetin etik değerleri olmadığ görüşü yanlıştır. Bütün toplumsal alanlarda olduğu gibi siyaset de etik bir içerik içermektedir. Siyasal eylemler genel kabul gören etik ilkelerle uyumlu olmayabilir. Bu durum siyasal eylemlerin etik dişı olduğu anlamina gelmez. $\mathrm{Bu}$, siyasetin kendine has bir etik sistemi olduğunun gösterir (Bayram, 2008: 18).

Hökelekli'ye göre toplumlar birlik ve beraberliği sağlayacak, başarılı liderlere ihtiyaç duyarlar. Toplumların devamlılığ 1 için bu şarttır. Fakat bu gücü elde etmek isteyen rakip gruplar arasındaki iktidar mücadelesi bazen çok aşırı noktalara (çatışma, hile ve entrika gibi) varabilmektedir. Hukuk ve ahlak dışı olan bu tür olaylar toplumsal hayatı zaafa uğratmaktadır (Hökelekli, 2008: 26).

Normal şartlarda insanlardan beklenen ahlaki davranış kalıpları ile hareket edildiği takdirde siyasi amaçlara ulaşmak daha mi kolay olur sorusuna cevap verilmesi siyaset-ahlak ilişkisini daha anlaşılır bir çerçeveye oturtacaktır.

Bulut'a göre siyaset-ahlak ilişkisi iki düzeyde ele alınabilir. Bunlardan birincisi siyasi eylemlerin hangi amaca dönük olarak ve hangi değerleri yaratacak şekilde ortaya konması gerektiğini ele alan siyaset felsefesidir. Bu alan çok geniştir ve "etik"in alanına girmektedir. İkincisi ise siyasi faaliyetlerin değerlendirilmesidir. "Siyasi ahlak" denen bu alanda siyasette genel kabul gören ahlaki ilkeler durur. Genel kullanımda siyasi ahlaktan bahsedildiğinde kastedilen şey, siyasette de genel kabul gören ilkelere uyulması 
gerektiğidir (Bulut, 2007: 2-3). Yani gerek sosyal ilişkilerde gerekse iş ilişkilerinde bireylerden hangi tavirlar bekleniyorsa, siyasal alanda da aynı çerçevede hareket edilmelidir.

Siyasetin hangi amaca dönük olarak gerçekleştirilmesi gerektiği konusu üzerinde eskiden beri tartışılmaktadır. Bu konuda üç farklı yaklaşım söz konusudur: a) Platoncu yaklaşım: Siyaseti ahlaka feda etmektedir. Bu yaklaşıma göre siyasetin/devletin vazifesi erdemi hayata geçirmektir. Dolayısıyla siyasete verilen görev bireyleri erdeme yönlendirmektir. "İdealist" diye de adlandırılan bu yaklaşıma göre evrensel doğrular vardır. Erdemi gerçekleştirmek için var olan devlet özellikle eğitim yoluyla vatandaşların erdemli bireyler olmasını sağlamalıdır. Vatandaşlara kendi ahlak anlayışını aşılaması devletin hakkıdır. Böyle bir devlet filozoflar tarafından yönetilmeli veya yöneticiler filozoflaşmalıdırlar (Bulut, 2007: 3)

Platon'un yaklaşım öğrencisi olan Aristo tarafından yumuşatılmış olmakla beraber, siyaset ile ahlak iç içe görülmeye devam etmiştir. Aristo'ya göre bireysel problemler ile devletin kurumlarının problemleri birbirinden ayrılamazlar. Devletin gayesi ortak mutluluğun elde edilmesidir. Siyaset bu en büyük iyinin gerçekleştirilmesinin bir aracından başka bir şey olarak görülmez. Platoncu yaklaşım İslam düşünürlerini de etkilemiştir. Farabi'de tıpkı Platon ve Aristo gibi ahlakı ve siyaseti birbirinden ayırmaz. İbn-i Rüşt ise siyaseti bir tür ahlak olarak görmüştür (Bulut, 2007: 3-4). Platoncu yaklaşım tarzı bireyin hareket alanını kısıtlayan baskıcı bir devletin ortaya çıkmasına neden olur (Dursun, 2005: 19). Ortak iyiyi gerçekleştirecek olan devlet olduğu zaman, ona baba rolü verilmiş olacaktır. Bireylerin neleri yapıp yapamayacağına devletin müdahalesi çok fazla olur. Toplumun ortak çıkarı adına bireysel özgürlükler sınırlandırılır.

b) Machiavellici yaklaşım: Batı'da modern politik ahlak Machiavelli ile başlamıştır. Politikanın gerçekte nasıl işlediğine bakarak politikanın gerçekleşiş tarzını ahlak ve erdem kaygısından bağımsız bir şekilde oluşturur. Ona göre insan doğası gereği kötüdür. Bu öncülle hareket ederek ahlak ile politikayı birbirinden ayırır (Aral, 2008: 12). Bu yaklaşıma göre siyaset ahlaki değerlere dayalı olarak gerçekleştirilemez. Prensin ahlaki ilkelere bağlı kalmaması gerektiğini savunan Machiavelli, halkın ahlaki ilkelere uyması gerektiğini savunur. Halkın yönetime sadakat ve vatan sevgisi gibi bir dizi ahlaki prensiple uyması gerektiğini savunur. Machiavelli ahlakı siyasetin emrine vermekte ve siyaseti ahlakın varlığının bir ön koşulu olarak görmektedir (Bulut, 2007: 5).

İş hayatında Makyavellist yaklaşımı temel alarak yapılacak uygulamaların sonucu bir çok açıdan olumsuz olacaktır. Kapitalist toplumlarda şirketlerin en büyük gayesi karı maksimize etmek olduğuna göre, bu amaç doğrultusunda atılacak bütün adımların bir açıklaması olacaktır. Karı arttırmak amacıyla çalışanlara olabildiğince düşük ücret vermek, maliyetleri düşürmek için sağlığa zararlı hammadde kullanmak ve gerektiğinde tüketicileri kandırarak ürünlerini yüksek fiyattan satmak vb. yöntemler meşru olarak görülebilecektir. Rakiplere dönük yapılacak her türlü karalama ve zarar verici eylem bir gereklilik olarak görülecektir.

c) Demokratik yaklaşım: Bu yaklaşıma göre devler kendi varlığının devamlılığını sağlamak için gerekli olan ahlaki değerlerin gelişebileceği ortamı oluşturacaktır (Dursun, 2005: 19).

Siyasi faaliyetler yürütülürken bazı ahlaki ilkelere uyulması gerektiği yönündeki yaklaşımda siyaset-ahlak ilişkisi daha somut bir çerçevede incelenebilir. Mesela bir siyasetçinin rüşvet almaması veya seçim masraflarını karşılamak için usulsüz yöntemlere başvurmaması gibi. Zenginlik ile siyaset arasında bir bağ bulunması dolayısıyla, eskiden beri siyasetin temiz olması gerektiği yönünde görüşler dile getirilmiş, birçok düşünür yöneticilere dürüst olmaları yolunda nasihatler içeren kitaplar kaleme almışlardır. $\mathrm{Bu}$ düşünürlerden Platon çok ileri gitmiş ve yöneticiler ile savaşçıların mal sahibi olmamaları gerektiğini savunmuştur (Bulut, 2007: 5-6).

Max Weber'e göre siyasetçiler ister idealis isterse bencil olarak bu işe yönelmiş olsun, ya 
kendi bireysel amacı için bir araç olarak görür yada sırf iktidarın sağladığı güç ve prestijden faydalanmak için siyasete yönelir (Yoldaş, 2007: 201).

Siyaset bir şekilde gücü elde etmenin yolu olarak görülmektedir. Gücü elde eden, devletin imkanlarını kendisi için ve destekçileri için arpalık olarak kullanma yoluna gidebilmektedir. Günümüzde siyasi partiler idealist amaçlardan ziyade ülke kaynaklarının toplumsal kesimler arasında dağıtımında belirleyici olma saikiyle hareket etmektedirler. Dolayısıyla gücü ele geçiren siyasi parti kendi yandaşlarının çıkarları doğrultusunda kamu imkanlarını kullanma yoluna gitmektedir. İşe alımlarda da kendine yakın olanlara öncelik vermektedir. Ahlaki yozlaşmanın siyaset alanındaki ayağı, iş ahlakının diğer kesimlerini de doğrudan etkilemektedir. Kamudan ihale almak isteyen şirketler siyaset kurumu ile uyumlu olmak zorunda kaliyorlar. Siyasal iktidarı elinde bulunduranlara belli avantajları sağlamadan bir ihaleyi kazanmak çok zordur. İhaleye giren şirketlerin kendi aralarında serbest rekabet anlayışı çerçevesinde hareket etmeleri söz konusu değildir. Siyaset kurumunun kokuşmuşluğu iş ahlakının kokuşmuşluğuna da neden olmaktadır.

Siyasal süreçte dört aktör yer almaktadır: Siyasal partiler, bürokrasi, seçmenler ve baskı ve çıkar grupları. Söz konusu olan aktörlerin her birisinin uyması gereken ahlak kuralları mevcuttur. Fakat siyasal süreçte en büyük ahlaki sorumluluk siyasal iktidarı elinde bulunduran iktidardadır (Sakal ve Kitapçı, 2009: 34-35). Çünkü karar alma merciinde olan ve toplumsal hayatın her alanına dönük düzenlemeler yapabilme gücüne sahiptir.

Günümüz dünyasında siyasetçilerin mülkiyet sahibi olmaması diye bir talepte bulunmak kabul görmeyecektir. Siyasilerin erdemli birer kişi olmalarını beklemek veya hukuki düzenlemeler ile onların erdemli olmalarını sağlamak da mümkün değildir. Fakat demokrasilerde yöneticilerin ahlaki kurallar çerçevesinde hareket etmeleri beklenir ve bunu sağlamaya dönük bazı hukuki düzenlemeler yoluna da gidilebilir (Bulut, 2007: 6). Siyasilere mülkiyet yasağı getirilmesinin mümkün olmaması onların mallarındaki hızlı artışı kontrol etme ve gerekli yaptırımları uygulamaya koymanın önünde bir engel olarak görülmemeli. Aynı şekilde iş dünyasının siyaset ile bağlantısının olmasını engellemek de mümkün değildir. Fakat siyasiler ile olan ilişkileri belli etik kurallar ile ve buna bağlı normlar ile sınırlandırılabilir. İş dünyasının kendi çıkarları doğrultusunda yasal düzenlemeler yapmak için siyasi partilerle iletişime girmeleri demokratik toplumun işleyişi ve sivil toplumun faaliyeti bağlamında değerlendirilebilir. Lakin amaçları doğrultusunda siyasilere rüşvet vermeleri gibi etik olmayan tavirlar sergilenmesinin engellenmesi için gerekli önlemler alınabilir.

Siyasal ahlakı bozucu olarak kabul edilen siyasi davranışlara siyasal yozlaşma denmektedir. Siyasal yozlaşma geniş ve dar anlamlarda kullanılmaktadır. Dar anlamda siyasal yozlaşmadan kastedilen, siyasilerin yolsuzluk, adam kayırma gibi eylemleridir. Geniş anlamda siyasal yozlaşmadan kastedilen ise seçmenlerin, özelliklede siyasetçi, bürokrat ve çıar gruplarının kendi menfaatleri uğrunda hukuki, kültürel, dini vb. değerleri çiğnemeleridir. Her iki durumda da temel belirleyici olan, sahip olunan gücün kendi kişisel çıkarları doğrultusunda bütün değerlere aykırı bir şekilde kullanılmasıdır. Siyasal yozlaşma yasalara aykırı bir şekilde gerçekleşebildiği gibi, yasal olarak suç olmamakla birlikte halkın ahlaki bulmadığı tavırlar şeklinde de (lobicilik, yalan vaat gibi) cereyan edebilmektedir (Bulut, 2007: 6-7). Özel sektörde de tıpk1 kamu sektöründe olduğu gibi liyakatten ziyade kişisel bağlantılarla hareket edildiği gözlemlenmektedir. İşe personel alınacağında torpili olanlar önceliklidirler ve torpil olmaksızın iş bulmak oldukça zordur. Burada özel sektörün yönetim kademelerindeki personel belirleyici olmaktadır. Ayrıca siyaset kurumundan gelen talepler çerçevesinde de personel alındığı söylenebilir. Dolayısıyla yozlaşmanın sadece siyaset kurumuna özgü bir olgu olduğunu söylemek doğru olmaz.

İktidarı ele geçiren kişilerin başkalarını ilgilendiren kararlar alabilmesi psikolojik dünyasında bir değişime yol açmaktadır. Bir 
kişinin başkaları üzerindeki etkisi arttıkça "kendilik algısı" değişim gösterir. Artık hükmettiği insanları kendi parçası olarak görmeye başlayabilir. $\mathrm{Bu}$ durumda kişinin benliğini diğer insanları da içine alarak genişletmesi, kendi iktidarının arttığı hissini verir. Böylece kendilerinde büyüklük, üstünlük, seçkinlik görmeye başlar. Kendisini mükemmel ve diğer insanları kendine ihtiyaçlı olarak görür. Diğer insanlarla ilişkilerinde eşitlik veya ortaklık bağlamında bir tutuma yanaşmaz (Hökelekli, 26-27). Büyük şirketlerin sahiplerinin topluma bakışları da farklı değildir. Elde ettikleri maddi güç onları toplumdan hem yaşam tarzı olarak hem de hayata bakış bağlamında farklılaştırmaktadır. Çalışanlarına karşı tavırları insancıl olmayabiliyor. Diğer insanlardan kendilerini daha üstün görmeye başlıyorlar.

Siyaset kurumu yoğun bir şekilde eleştirildiği halde insanların siyasete olan bu ilgilerini nasıl açıklamak gerekir? Bir başka deyişle, her gün eleştirilen siyaset kurumunda etkin bir rol elde etmek için mücadele edilmesinin nedeni nedir?

Siyaset kurumu kendi yandaşlarına imkanlar sağlamaktadır. Toplumsal kesimler iktidara yakın oldukları oranda devlet imkanlarından faydalanabilmektedirler. Aslında siyaseti rüşvet dağıttığ tabi tutmak çok da hakça bir yaklaşım değildir. Siyaset kurumu toplumsal yapının bir aynasıdır. Rüşvet ve yolsuzluğun toplumsal katmanlarda yaygın olduğu toplumlarda siyaset kurumunun etik davranmasını beklememek gerekir. İş dünyasında da durum çok farklı değildir.

Siyasetin nasıl yapıldığı kadar niçin yapıldığ da önemlidir. Demokrasinin yerleşmiş olduğu toplumlarda siyasi parti liderleri başarılı olup olmamalarına göre değerlendirilir. Siyasetçinin başarısının en somut göstergesi siyasal iktidarı ele geçirme derecesiyle orantılıdır. Bir siyasetçinin çok başarılı olması, onun aynı zamanda çok erdemli dürüst ve iyi bir insan olduğunu garanti etmemektedir (Akyüz, 2009: 99).

Siyaset ahlakına meslek ahlakı bağlamında da yaklaşılabilir. $\mathrm{Bu}$ çerçevede siyasi ahlak, siyasetçi ve bürokratların kamu hizmetlerini ifa ederlerken uymaları gereken ahlaki kurallardan oluşmaktadır. Siyasete dönük eylem ve faaliyetlerin temel dinamiğini "menfaat" oluştururken, ahlaki eylem ve davranışlarda ise "vazife" anlayışı itici güçtür (Dursun, 2005: 20).

Siyaset özü itibariyle bazı yönlerden ahlaka karşı ilkeler taşımaktadır. Siyasetin olduğu her yerde yöneten ve yönetilen ilişkisinden bahsedilebilir. Küçük bir azınlığın geniş halk tabakalarını yönetmesi eşitlikçi değildir ki bu durum ahlakın doğasına aykırılık teşkil etmektedir. Toplumsal çıkarların oluşumu ve bölüşümünde de siyaset kurumu önemli ölçüde belirleyicidir. Yine bu çerçevede bakılacak olursa siyasetin işlevi de ahlakilik bağlamında tartışılabilir. Toplumsallaşmanın nasıl gerçekleşeceğine de önemli ölçüde siyaset kurumu karar vermektedir. Toplumun tamamına dönük kararlar vermektedir (Akyüz, 2009: 104).

Toplumda ahlaki anlamda bir yozlaşmanın olduğu düşünülmeye başlandığında çözüm bir çok ithamla suçlanan siyaset kurumundan beklenmektedir. Siyaset ahlaki anlamdaki düzeltme hareketinin de başlangıç noktası olarak gözükmektedir. Toplumların beklentisi erdemli bir siyasetin yürütülmesidir. Siyaset kurumu ise bu konuda topluma söz vermektedir. Toplum zaman içinde sözünde durmayan, ahlaki zaafları olan siyasileri ayıklama yoluna gitmektedir (Akyüz, 2009: 104).

Bilgi toplumunun bir sonucu olarak bireyler haklarını ve yükümlülüklerini daha iyi biliyorlar. İletişim kanallarının olabildiğince yaygınlaşması ile birlikte gerek ülkelerinde gerekse dünyanın farklı coğrafyalarında meydana gelen olaylardan haberdar olan vatandaşlar, basının da katkıları ile siyaset kurumunu daha sıkı takip etme ve yapılanları sorgulama noktasına gelmiştir. Sivil toplum kuruluşlarının sayısının ve etkisinin hızla artması, vatandaşların daha organize hareket etmelerine neden olmuştur. Siyasetçilerin yapmış oldukları gayri ahlaki faaliyetlerin kısa zamanda geniş kesimlerce duyulmasının sonucunda nasıl olumsuz sonuçlarla karşılaşıldığ1 bir çok örnekle gündeme 
gelmiştir. Bütün bu gelişmeler siyasetçilerin katılımcilığı daha fazla önemsemelerine ve şeffaflık ve dürüstlük gibi ilkelere karşı daha duyarlı olmalarına neden olmuştur (Torlak, 2008: 72).

Bireysel olarak yapılan yanlışlar hata olarak görülürken, siyasilerin yaptığı yanlışlar çok ağır şekilde itham edilmektedir. Siyasetçinin bireysel tavırları ve siyasetçi kimliği ile gerçekleştirdikleri farklı bir şekilde değerlendirilmelidir. Siyasetçi çok sayıda seçmenle irtibat halindedir ve onların desteğini sağlamak için vaatlerde bulunması bir zorunluluktur. İnsanlar kendilerine vaatlerde bulunmayan siyasetçilere oy vermemektedirler. Siyasetin doğası gereği bu sözler verildikten sonraki dönemde gereği farklı nedenlerden dolayı yerine getirilemeyebiliyor. Bütçedeki yetersizlikler veya başka nedenlerle bu sözler gerçekleştirilememiş olabiliyor. Bu şartlarda siyasileri ahlaksızlıkla suçlamak pek doğru olmaz.

\section{İş, Çalışma ve Meslek Etiği}

İş ve meslek ahlakı anlayışının kökenleri eski tarihlere kadar gitmektedir. meslek dendiği zaman akla sinırlı sayıdaki faaliyet gelmekteydi. Dini metinlerde ticareti bazı ahlaki kurallara bağlayan yaklaşımlar bulunmaktadır. "ticaret ahlakı" meslek ahlakının bilinen en eski türüdür (Özen, 2011: 179). Anadolu'ya yerleşen Türklerde geliştirilmiş olan ahilik teşkilatı etik yaklaşımın en güzel uygulama örneğini teşkil etmektedir. Ahilik anlayışı maddi ve manevi boyutuyla hayatı dengeli yaşamayı amaç etmiştir. Ahilik, yeryüzündeki bütün varlıkların ve bu bağlamda doğanın, canlıların bir bütün olarak Allahın emaneti olduğu anlayışıyla hareket etmekte ve gerek doğanın gerekse emeğin sömürülmesine karşı çıkmaktaydı. Toplumu dayanışmacı bir anlayış ile kucaklamakta olan ahilik, fakir ile zengin, sermaye ile emeğin birbirinin rakibi değil tamamlayıcısı olduğunu düşünür ve toplumun refahını ve huzuru temin için bütün kesimlerin birlikte çalışmaları gereğine inanırdı. Ahlaki olmayan bütün davranışlara karşı çıkan bir anlayıştı (Durak ve Yücel, 2010: 152).
Küreselleşme, çalışanların ve müşterilerin artan beklentileri ve toplumsal duyarlılıkta görülen hızlı yükseliş beraberinde işletmelerin sadece iktisadi birer birim olmaktan ziyade aynı zamanda sosyal sorumlulukları olan birimler olduğu anlayışını hakim kılmıştır. Bu çerçevede işletmelerin etik ve sosyal sorumlulukları ile paydaşlarına karşı sorumlulukları yeniden tanımlanmaya çalışılmıştır. 2000'li yıllara gelindiğinde iş etiği ile ilgilenmeyen ve iş etiğine dönük kurumsal çalışmalar içine girmeyen işletme hemem hemen hiç kalmamıştır (TÜSİAD, 2009: 15).

Etiğin bir alt kümesi olan iş etiği iş dünyasındaki etik sorunları ele alır, davranışlara rehberlik etmek amaciyla kurallar geliştirmeyi amaçlar. Çalışma ve meslek etiğini de kapsayan iş etiği, bir taraftan işletmelerin ürün ve hizmet üretmeleri ve dağıtmaları sürecinde hem örgüt hem de çalışanın davranışlarının etik çerçevede gerçekleşmesi üzerinde yoğunlaşır ve bu bağlamda yol gösterici kurallar ortaya koymaya çalışır (TÜSİAD, 2009: 15). İş etiğini açıklamaya çalışan tanımların tamamı, belli bir konuda "doğru ve yanlışın” ne olduğu, buna dönük ilke, standart ve kuralların neler olduğunun altını çizmektedir. Herhangi bir davranışın etiğe uygun olup olmadığını kişisel etik anlayışı ile değil, toplumun genel kabulleri ile ortaya koymak mümkün olabilir (Erturhan ve Filizöz, 2011: 141-142).

Meslek etiği, çalışma yaşamında meydana gelen sorunları çözmeye çalışan, kamu görevlilerinin, yöneticilerin ve vatandaşların birbirlerine dönük tutum ve ilişkilerini ahlaki çerçevede ele alan felsefe dalıdır. Meslek etiği ilkeleri evrenseldir (Usta, 2012: 411). Mesleklerin evrensel olan ilkelerinin yanında mesleklerin kendine özgü bazı ahlak ilkeleri de bulunmaktadır (Özen, 2011: 179).

Meslek etiği, uygulamalı etik içerisine girmektedir ve sadece ahlaki değer ve normları incelemekle yetinmez, aynı zamanda elde ettiği sonuçları kurumlara, iş görme biçim ve faaliyetlerine ve teknolojilere uygular. Bundan dolayı "çalışma ahlakı" ve "meslek etiği" iç içe girmişlerdir (Usta, 2012: 411). 
Her hangi bir işin meslek sayılabilmesi için bazı koşullar bulunmaktadır. Her şeyden önce meslekler belli bir uzmanlaşmayı ve akademik eğitimi gerektirir. Her meslek, bu mesleği icra edenlerden özverili davranışlar bekler. Mesleklerin üyelerini kapsayan birer meslek örgütü olmalıdır. Meslek sahipleri görevlerini yetine getirirken aynı zamanda kamusal hizmet de yapmış olurlar. Doktor hastaya görevi olduğu düşüncesiyle (para kazanmak için değil) bakar ve hastaya baktığ 1 içinde para kazanır (Güner, 2002: 22-23). Her mesleğin kendine özgü koşulları vardır. Mesleklerin kendi özel koşullarına göre doğru ve yanlış olarak nitelenerek hayata geçirilen ilkelerdir meslek etiği (Yıldırım, 2005: 231) Bir mesleğin mensuplarının uyması gereken etik kurallara meslek etiği denmektedir. Genellikle söz konusu ilkeler gelenek ve değer yargilarından bağımsızdır. Belli bir iş ortamında doğru ve yanlış şeklinde ortaya konan davranış modellerini irdeler ve insanların davranışlarında dürüst, adil, haksızlıklara karşı tavır koyan, saydam, demokratik tutum geliştiren, doğaya ve insana saygılı olmaları gibi ahlaki ilkelerin gerekçelerini inceler (Usta, 2012: 412). Meslek etiği, meslek mensupları tarafından genel kabul gören ilkeler olduğundan dolayı, bu kurallara uygun çalışanlar güvenilir bulunur ve meslek çevrelerince sayg1 görürler. Her şeyden önce vicdanları rahat olur (İşüden ve Çabuk, 2006: 59).

Etiğin öneminin kavranması sonucunda giderek her mesleğin kendi etik ilkelerinin oluşmasını ve bu alanda kurumsallaşmanın yolunu açmıştır (İlhan, 2005: 260). Meslek etiği sadece siyaset, kamu, medya ve tıp gibi alanlarda çalışanlara dönük değildir. Meslek etiği, mesleki alanlarda belli durumlarda personelin nasıl davranmaları gerektiğini belirleyen ahlaki ölçüt ve ilkeleri geliştirerek, bir taraftan hizmet görenlerin, diğer taraftan da mesleğin zarar görmesini engellemeye çalışmaktadır (Usta, 2012: 412). Meslek etiği açısından yükümlülük, sorumluluk ve ödev gibi kavramlar çok önemlidir. Meslek sahipleri işlerini yerine getirirken kendi çıkarlarının yanında meslektaşlarının, vatandaşların ve devletin de çıarlarını gözetmek ve bu bağlamda sorumluluklarını yerine getirmek zorundadırlar (İşgüden ve Çabuk, 2006: 61).

İşletmelerde karşılaşılan ahlaki sorunlar etik sapma ve etik ikilem olarak iki gruba ayrılmaktadır (Özen, 2011: 177). Meslek etiği, etik sapmalardan ve etik ikilemlerden olumsuz bir şekilde etkilenmektedir. Etik sapmadan kasit, etik olmayan kararların alınmasıdır. Etik ikilem ise, bir konunun birbiri ile tezat oluşturan iki tarafının bulunması ve bu iki farklı tarafın da savunulabilecek ve eleştirilecek yönlerinin olması durumudur. Günlük hayatımızda etik ikilemlerle sı sık karşılaşılmaktadır. $\mathrm{Bu}$ durumda yapılması gereken, kimlerin alınacak kararla nasıl etkileneceğinin iyice düşünülerek hareket edilmesidir. Ancak bu yolla etik ikilemi çözmek mümkün olabilir (İşgüden ve Çabuk, 2006: 63).

İşe karşı bir toplumda geliştirilen tutum ve davranışlara çalışma etiği denir (TÜSİAD, 2009: 15). İşe karşı geliştirilen tutum ve davranışlarda içinde yaşanılan toplumun kültür ve değerlerinin etkisi olmaktadır. Sadece bireylerin değil, aynı zamanda toplumların ve grupların da kendine has çalışma ahlakı söz konusu olabilir. Bireylerin çalışma ahlakının oluşmasında içinde yaşanılan toplumun yanında, ailenin, deneyimlerin, kişiliğin, özel koşulların da etkisi olmaktadır (Usta, 2012: 412).

Etik davranış kalıplarına uyulmasını zorunlu kılan sebepler her gün biraz daha artmakta ve şirketlerin uzun vadede başarısının artmasında etkili olmaktadır. Şirketlerin gerek ulusal gerekse uluslararası alanda kalıcı olmalarının temelinde iyi bir imaja sahip olmaları önemli bir yer tutmaktadır. İmajın iyi olmasının yolu etik kurallara uygun olunmasına bağlıdır. İmajı sağlam olan şirketler kurumsallaşmalarını daha hızla sağlarlar ve güvenilirlikleri artar. Böylece daha geniş bir tüketici kitlesi tarafından ürünlerine uzun vadeli olarak talep oluşur (Illhan, 2005: 259-260).

İş hayatında güvenin yerleşmesi, iş hayatında etik olmayan davranışların önüne geçilmesi için bazı etik ilkelere göre hareket edilmesi bir zorunluluktur. İş etiğinin ilkeleri şunlardır: Dürüstlük, hukuka sayg1, bilgi elde etme, kullanma ve saklama, çalışma ortamı ve 
çalışanlar, siyasi partilerle ilişkiler ve çevreyle olan ilişkilerde erdemli davranmak (TÜSİAD, 2009: 17).

Etik olmayan tavırların temelinde, kişisel çıkar veya örgütün çıkarını temel alan, bu çıkarı en üst seviyeye çıkartma anlayışı çerçevesinde etik kuralların ihlali yatmaktadır. Etiğe uygun olan ve olmayan davranışları etkileyen faktörleri dört ana kümede toplamak mümkündür.. $\mathrm{Bu}$ dört kümenin de kendi içinde alt faktörleri vardır. TÜSİAD’a göre bu faktörler şunlardır:

1) Kişiye ilişkin etmenler; a) Kişinin değerleri, b) Kişinin Öncelikleri; c) Kişinin pozisyon ve kıdemi, d) Kişinin Tecrübeleri, e) Kişinin demografik özellikleri, f) Kişinin etik dişı davranışın olası getiri ve götürüleri hakkında risk değerlendirişi.

2) Eyleme ilişkin etmenler; a) Açık etik ihlali, b) Gri alanlar, c) Etkilenen kişilergruplar, d) Durumsal faktörler.

3) Kuruma ilişkin etmenler; a) Kurumun yönetim felsefesi, tarihi, görüntüsü, b) Değerleri ve kültürü, c) Etik kodları ve etik eğitimi, d) Bulunduğu sektör ve rekabet durumu.

4) Çevreye ilişkin etmenler; a) Ekonomik çevre, b) Siyasal çevre, c) Sosyal kültürel çevre, d) Diğer etmenler (yargı süreci, medya, STK ve uluslararası kuruluşlar) (TÜSİAD, 2009: 19-20).

Kanuna uygun olması bir eylemi etik yapmaya yetmemektedir. Firmalar maliyetlerini düşürmek için uygun olmayan ambalajlama yöntemlerini kullanabileceği gibi, reklamlarda cinselliğin aşırı derecede ön plana çıkarılması veya ürünlerini test etmek için hayvanlar üzerinde etik olmayan deneylerin gerçekleştirilmesi gibi eylemler kanuna uygun olsa bile ahlaki olarak kabul edilemezler (Torlak, 2008: 69).

İş etiğini ekonomi ile ahlakın evliliği olarak tanımlamak mümkündür (Özgener, 200: 176) İş etiği işletmenin hemen bütün faaliyet alanlarını kapsamaktadır. Bu bağlamda iş personel alımı, ihaleye karar vermek, birini korumak, kaynakları tahsis etmek, fiyatları belirlemek, kar payını belirlemek, çalışanları disiplin altına almak, kontratları değerlendirmek vb. alanların tamamı iş etiği ile ilintilidir (İlhan, 2005: 260).

İş etiğinin gayesi, bazı kolaylaştırıcı kurallar bütünü oluşturarak işadamlarının üretmiş oldukları ürün ve hizmetlerin vatandaşların güvenini kazanmasını sağlamaktır (Smith ve Smith, 2007: 383).

İşletmeler açısından sosyal sorumluluk iş etiği bağlamında önemlidir. İşletmeler yaptıkları faaliyetlerden dolayı toplumun zarar görmemesi için gerekli önlemleri almalı ve bu konuda duyarlı olmalıdır. 1980'den sonraki dönemde hakim olan anlayışa göre işletmelerin tek gayesi kar elde etmek değil, topluma hizmet etmenin temel amaç olduğu, karın, yapılan iyi hizmetin bir ödülü olduğu anlayışı dile getirilmeye başlanmıştır (Demir, 1999: 151-152). Sosyo-ekonomik yapının genel olarak çok da ahlaki ilkeler çerçeve içerisinde işlediği söylenemez. Böyle bir yapı içerisinde ahlaki hareket etmek kısa vadede faydalı olmayabilir ve hattı bazı olumsuz maliyetlere sebep olabilir. Fakat uzun vadede bakıldığında etik davranışın olumlu sonuçlar doğurduğu gözlemlenebilir. Küreselleşme ile birlikte ortaya çıkan tüketim anlayışı da önemli ölçüde eski alışkanlıklardan farklılık arz etmektedir. Tüketim alışkanlıkları ve taleplerinin hızla değiştiği Post-Fordist dönemde tüketici, merkezi bir yere sahiptir. İşletmeler varlıklarını sürdürebilmek için bir taraftan tüketici taleplerindeki değişime ayak uydurmak zorundayken, diğer taraftan da onların güvenini sağlama yoluna gitmelidir. $\mathrm{Bu}$ durum insan merkezli bir üretimin ön plana çıkmasına neden olmuştur ve etik değerlere daha fazla dikkat edilmek zorunda kalınmıştır. Firmalar iyi bir imaja sahip olabilmek için devletle ve rakipleriyle olan işlerinde de etik olmak durumundalar. Vergi kaçıran, kaçak işçi çalıştıran bir firmanın imajı iyi olamaz. Aynı şekilde başka firmaların ürünlerini taklit eden, onlara karşı gayri ahlaki bir rekabet içine giren firmanın imajı yine olumsuz etkilenir (İlhan, 2005: 261-263). 


\section{Sonuç}

Siyaset ahlakı ile ilgili olarak iki tezat görüşün olduğu söylenebilir: Kimilerine göre siyaset ahlakı ile genel ahlakın ilkeleri birbiri ile uyumlu olmalı, normal hayatta etik olarak kabul görmeyen tavırların siyaset için de etik görülmemelidir. $\mathrm{Bu}$ yaklaşımın tam aksi yöndeki yaklaşıma göre ise siyaset için geçerli olan etik kurallar ile toplumsal ahlak anlayışı farklı olmak zorundadırlar.

Siyaset ahlakını genel etik ilkelerle sinırlandırmak bazı noktalarda sikıntılı sonuçlara neden olabilmektedir. Uluslararası ilişkilerde reel politik yaklaşımı görmezden gelerek, ütopik söylemlerle siyasilerin ülkelerinin genel çıkarını korumaları mümkün olamaz. Diğer ülkelerle gerek barış zamanında gerekse savaş döneminde tam manasıyla şeffaf, dürüst, ilkeli ilişki yürütmek anlamlı değildir. Bugün dost olan bir ülke bir süre sonra düşman olabilmektedir. Devletler kendi ülkelerinin çıkarlarını korumak veya yeni çıkar alanları elde edebilmek için bir çok yola başvurabilirler. Azgelişmiş ve gelişmekte olan ülkelerdeki gerek darbeler gerekse iç çatışma ve karışıklıklar büyük ölçüde diğer devletler tarafından yönlendirilmekte ve desteklenmektedir. Böyle bir dünyada bir devletin farklı politikalar geliştirip uygulaması bir zorunluluktur. Zamana ve şartlara göre tavır geliştirme ve kendine yeni alanlar açma yoluna gitmek kaçınılmazdır.

Diplomasinin bir zorunluluğu olan bu durum siyasetin her alanına sirayet ettiği zaman, işin içinden çıkılmaz olur. Siyasilerin de genel kabul gören etik değerlerle bağlı oldukları alan bütün diğer siyasi faaliyetleri kapsamaktadır. Siyasilerin dürüst olması, adam kayırmaması, rüşvet almaması vb. bir zorunluluktur. Siyasi faaliyetlerin de açık bir şekilde ve ahlaki ilkelere uygun olarak yürütülmesi gerekmektedir.

Siyasilerin dürüstlüğünü seçim öncesi vaatlerine göre değerlendirmek de sakıncalıdır. Hiçbir vaatte bulunmayanın seçilme şansının pek olmadığı göz önünde bulundurulmalıdır. Siyasiler kendi hayallerini samimi bir şekilde anlatarak oy isteyebilirler. Seçimden sonra ortaya bir koalisyon hükümeti çıkabilir, ekonomik kriz olabilir veya daha farklı önceliklerin varlığının farkına varılabilir. Bu durumda sözünü yerine getiremediği için ahlaksızlıkla suçlamak doğru olmasa gerek.

İş ahlakı hem çalışanlar, hem tüketiciler hem de çevre açısından çok önemlidir. İşletmeler kurum içerisinde çalışanlar arasında ayrımcılık yapmamalı, ödül ve yükselme kriterleri şeffaf olmalıdır. Tüketicilere karşı dürüst ve şeffaf olunmall, ürün ve hizmetlerin günün kabul gören standartlarına uygun olmasina, müşterilerin hiçbir şekilde (reklam vb) aldatılmamasına özen göstermelidirler.

İşletmelerin çevreye karşı da sorumlulukları bulunmaktadır. Uzun dönem varlığını sürdürmek isteyen işletmeler içinde yaşadıkları çevreye sayg duymalı ve ona zarar vermemek için gerekli özeni göstermelidir.

İşletmeler para hırsılyla her yöntemi mubah gören bir yaklaşım sergilememeli, rakiplerine karşı düşmanca bir tavır sergilememelidir. Rakiplerine karşı imha edecek şekilde bir rekabet içine girerek tekelleşme yoluna gitmek isteyen işletmeler toplumun sempatisini kazanamazlar.

İş ahlakının yerleşmiş olması toplumsal huzurun, güvenin yerleşmesi ve ülkelerin kalkınması açısından çok önemlidir. Vergisini zamanında ve düzgün bir şekilde ödeyen, çalıştırdığı elemanların hakkını ödeyen, tüketicilere düzgün mal ve hizmet üreten işletmelerin bulunduğu toplumlarda ahlaki yozlaşma da olmaz. 


\section{KAYNAKÇA}

AKTAY, Yasin (2008), "İslam Siyaset Felsefesinde Değer Algısı”, Dem Dergi, Y11:2, Sayı: 5, s.8-15

AKYÜZ, Ünal (2009), "Siyaset ve Ahlak", Yasama, Sayı: 11, s. 93-129

ARAL, Halide (2008), “İçbütünlük Sorunu ve Modern Politik Ahlak", Çankaya Üniversitesi FenEdebiyat Fakültesi, Journal of Arts and Sciences, Say1: 10, s. 11-17

BAYRAM, Ahmet Kemal, (2008), "Modern Zamanlarda Etik ve Siyasal Değerler". Dem Dergi, Y1l:2, Sayı: 5, s.16-23

BOLAT, Tamer ve Aytemiz Seymen (2003), “Örgütlerde İş Etiğinin Yerleştirilmesinde “Dönüşümcü Liderlik Tarzı"nın Etkileri Üzerine Bir Değerlendirme", Balıkesir Üniversitesi Sosyal Bilimler Enstitüsü Dergisi, Cilt: 6, Sayı: 9, s.59-85

BULUT, Nihat (2007), “Siyaset-Ahlak İlişkisi Bağlamında Siyasi Etik Komisyonu Kurulması Çalışmalarının Değerlendirilmesi”, EÜHFD, C. XI, S. 3-4 s.1-28

ÇAM, Esat (2000), Siyaset Bilimine Giriş, Der Yayınları, İstanbul

DEMİR, Hulusi (1999), “Sosyal Sorumluluk ve İş Ahlakı", Balıkesir Üniversitesi Sosyal Bilimler Enstitüsü Dergisi, Cilt: 2, Sayı: 3, s.150-168

DURAK, İbrahim ve Atilla Yücel (2010), “Ahiliğin Sosyo-Ekonomik Etkileri ve Günümüze Yansımaları", Süleyman Demirel Üniversitesi İktisadi ve İdari Bilimler Fakültesi Dergisi, C. 15, Sayı: 2, s.151-168

DURSUN, Davut (2005), "Siyaset ve Ahlak; Gerçeklikle İdealin Bağdaşmazlığı Sorunu", 2. Siyasette ve Yönetimde Etik Sempozyumu, 18-19 Kasim 2005, Sakarya, http: //www.etiksempozyumu.sakarya.edu.tr/etik/1.1/durs un.pdf, Erişim Tarihi: 20.10.2012

ERTURHAN, Hilal ve Berrin Filizöz (2011), “İş Etiğ ve Bankacılık Sektöründe Bir Araştırma", C.Ü. İktisadi ve İdari Bilimler Dergisi, Cilt: 12, Say1: 2, s.139-157

GÜNER, Semih (2002), "Avukatlık Meslek Etiği", Ankara Barosu Dergisi, Sayı: 2, s.19-31

HÖKELEKLİ, Hayati (2008), “Güç İsteği, Siyaset ve Değer İlişkisi”, Dem Dergi, Yı1:2, Sayı: 5, s.24-29

İLHAN, Süleyman (2005), "İş Ahlakı: Kuramsal Bir Yaklaşım", Afyon Kocatepe Üniversitesi Sosyal Bilimler Dergisi, Y11: 7, Sayı: 2, s.258-275
İŞGÜDEN, Burcu ve Adem Çabuk (2006), “Meslek Etiği ve Meslek Etiğinin Meslek Yaşamı Üzerindeki Etkileri", Balıkesir Üniversitesi Sosyal Bilimler Enstitüsü Dergisi", Cilt: 9, Say1: 16, s.59-86

KAPANİ, Münci (1997), Politika Bilimine Giriş, 9. Baskı, Bilgi Yayınevi, Ankara

ÖZEN, Yener (2011), “Sorumluluk Bağlaminda İş Ahlâkı Ve Sosyal Sorumluluk: Sosyal

Psikolojik Bir Yaklaşım", Gümüşhane Üniversitesi Sosyal Bilimler Elektronik Dergisi, Sayı:4, s. 173-189

ÖZGENER, Şevki (2000), “Ekonomik Sistemler ve Ahlâk", Süleyman Demirel Üniversitesi İktisadi ve İdari Bilimler Fakültesi Dergisi, C. 5, S. 1, s.175-190

ÖZTEKİN, Ali (2001), Siyaset Bilimine Giriș, 3. Baskı, Siyasal Kitabevi, Ankara

POYRAZ, Hakan (), “Siyasi Ahlakın Coğrafi Sınırları: Ahlak Felsefesi ve Siyaset", Yerel Siyaset, s.16-20

SAKAL, Mustafa ve KİTAPÇI, İsmail (2009), "Siyasal Ahlak Dışı Davranışlara Farklı Bir Çözüm: Anayasal İktisat ve Ahlak Anlayışı", Sosyoekonomi, sayı: 2, s. $32-48$

SMITH, Katherine T. Ve L. Murphy Smith (2007), "İş ve Muhasebe Etiği", Çev.: İsmail Bekçi, Süleyman Demirel Üniversitesi İktisadi ve İdari Bilimler Fakültesi Dergisi, C. 12, S. 3, s.381-386

TORLAK, Ömer (2008), “Pazarlama ve Erdemlilik: Yanlış Algılar İçin Bir Açılım", İş Ahlakı Dergisi, Cilt: 1, Sayı: 1, s.67-79

TÜRKÖNE, Mümtaz'er (2008), Siyaset, 8. Baskı, Lotus Yayınevi

TÜSİAD (2009), Dünyada ve Türkiye'de İș Etiği ve Etik Yönetimi,

http://www.tusiad.org/ rsc/shared/file/Tusiadisetigiraporupdf.pdf, E.T.12.12.20012

USTA, Aydın (2012), “Kamu Örgütlerinde Meslek Etiği ve Çalışma Ahlakı Üzerine Bir Değerlendirme", Süleyman Demirel Üniversitesi İktisadi ve İdari Bilimler Fakültesi Dergisi, C. 17, S. 1, s.403-421

YILDIRIM, Bilal (2005), “Eğitim Örgütlerinde Kültürel Liderlikle Meslek Ahlakı İlişkisi", Balıkesir Üniversitesi Sosyal Bilimler Enstitüsü Dergisi", C. 8, S.13, s.218-238

YOLDAŞ, Yunus (2007), “Max Weber'in (Siyasi) Sorumluluk Etiği Anlayışı", Süleyman Demirel Üniversitesi İktisadi ve İdari Bilimler Fakültesi Dergisi, C. 12, S. 2, s.199-218 